\title{
KEPEMIMPINAN GEMBALA: SUATU KAJIAN FILOSOFIS TENTANG PROSES INTEGRASI KEPEMIMPINAN ROHANI DAN SEKULER
}

\author{
Nicodemus Yuliastomo \\ e-mail: yuliastomo@yahoo.com \\ Ivan Th. J. Weismann \\ ivanweismann@yahoo.com
}

\begin{abstract}
ABSTRAK
Tugas gembala jemaat untuk memelihara umat Allah, merupakan tugas yang sangat strategis. Pada satu sisi manusia diperhadapkan kepada kompleksitas permasalahan yang semakin lama semakin rumit. Gereja melalui fungsi penggembalaannya bisa menjadi tempat bagi orang-orang untuk mendapatkan jawaban dan pertolongan dalam hidupnya. Pada sisi yang lain dengan tingkat perkembangan sumber daya manusia dan ilmu pengetahuan yang semakin maju, gereja sebenarnya bisa memanfaatkannya untuk pelayanan secara maksimal. Realitanya, sekarang orang lebih mencari jawaban melalui apa yang ditawarkan para pofesional dunia. Gereja dianggap ketinggalan jaman dalam upaya menjalankan tugas dan fungsinya. Melalui berbagai pandangan dan survei yang ada, diperoleh kesimpulan bahwa salah satu penyebab kemunduran gereja adalah tidakberfungsinya kepemimpinan gembala dengan baik. Mengingat kondisi seperti ini kepemimpinan gembala mesti digali, dikaji, dan dikembangkan, salah satu diantaranya melalui pendekatan dengan bidang lain, dalam hal ini integrasi kepemimpinan rohani dan sekuler. Melalui tehnik pengumpulan data literatur (Library Research), yaitu melakukan penyelidikan terhadap buku-buku dan tulisantulisan yang berkaitan dengan karya ilmiah, berdasarkan pendekatan : hermeneutik, komparatif, evaluasi dan induksi dan diduksi. Tujuan dari penelitian ini untuk memperoleh pengertian kepemimpinan gembala sebagai proses integrasi kepemimpinan rohani dan sekuler serta kontribusinya bagi pelayanan gereja, sehingga gembala dan gereja dapat menjalankan pelayanannya dengan baik.
\end{abstract}

Kata kunci: Kepemimpinan gembala, integrasi, kepemimpinan rohani, kepemimpinan sekuler

\section{PENDAHULUAN}

\section{Latar Belakang}

Menurut penulis, dewasa ini meskipun para gembala telah memerankan tugasnya sebagai pemimpin dalam proses penggembalaan umat, namun kepemimpinan gembala tidak berjalan sesuai kondisi dan tuntutan zaman. Kondisi ini diantaranya dipaparkan oleh Derek J. Tidball dalam bukunya "Teologi Penggembalaan." Derek J. Tiball mengemukakan bagaimana kepemimpinan gembala saat ini sedang digugat: Pertama, Peranan gembala jemaat diganti. Banyak hal yang secara tradisional biasanya dilakukan gembala jemaat sebagai satu-satunya orang yang berpendidikan sejak lama telah diambil alih oleh profesi-profesi yang lain; psikiater, dokter, konsultan dll. Kedua, Gambaran penggembalaan sudah dianggap kuno. Memandang pendeta serupa dengan seorang gembala memang masuk akal dalam suatu dunia yang pada dasarnya terdiri atas komunitaskomunitas pedesaan. Namun di dunia yang modern ini analogi domba dan gembala adalah

\footnotetext{
${ }^{1}$ Tidball, Derek J. Teologi Penggembalaan. Malang:Gandum Mas, 1998
} 
pemandangan yang tidak lazim dan tidak lagi mempunyai arti. Perubahan struktural sosial mempengaruhi kita secara lebih mendalam dari yang kita sadari. Kita memaksakan suatu kerangka rasional dan ilmiah kepada dunia kita dan tidak lagi mendekati persoalan-persoalannya sebagai misteri-misteri besar, tetapi hanya sebagai masalah-masalah yang perlu dipecahkan melalui kemajuan tehnologi. Ketiga, Struktur-struktur penggembalaan dalam gereja telah dianggap ketinggalan jaman. Penyusunan struktur di dalam birokrasi gereja dilihat terlalu sederhana dan umum, sehingga tidak efektif dan menyentuh persoalan yang rumit dan kompleks. Keempat, Jabatan penggembalaan sedang digugat. Gereja sendiri sedang mengalami gejolak perubahan. Dasarwarsa 1960-an membuyarkan pandangan bahwa hal memiliki suatu gelar atau jabatan sudah cukup untuk membuat orang lain menerima apa yang dikatakan tanpa bertanya lagi. Sekarang wewenang harus diperoleh sebagai imbalan dan disahkan oleh pengalaman pribadi dan bukannya sebagai label kelembagaan. Hal ini juga terjadi dalam jabatan gembala. Kelima, Pendekatan penggembalaan dianggap ketinggalan zaman. Sementara sistem kepemimpinan di dunia sekuler terus menerus diperbarui supaya lebih efektif, namun sistem penggembalaan setelah sekian abad usianya secara umum tetaplah sama. Keenam, Batas-batas penggembalaan sedang kabur. Berpangkal dari kesadaran yang semakin besar bahwa Allah tidak dibatasi untuk bekerja di dalam dan melalui gereja saja dan kebenaran tidak ditemukan hanya dalam lingkungan gereja, maka seringkali permasalahan manusia tidak lagi memerlukan pemecahan dari gereja.

Berdasarkan argumentasi yang dikemukakan Derek J. Tidball, kenyataan tersebut tentu membuat pelayanan gereja tidak berjalan sesuai secara baik. Padahal kepemimpinan gembala sangat berpengaruh bagi pelayanan dan perkembangan gereja.

Mempertimbangkan tuntutan terhadap kepemimpinan gembala dalam gereja, perlu menindaklanjuti apa yang ditegaskan Myron Rush,“ Bahwa organisasi Kristen harus mulai memberikan lebih banyak perhatian pada pelatihan manajemen dan kepemimpinan, karena tanpa manajemen yang berhasil-guna, suatu organisasi tidak dapat menjalankan misi pelayanannya seproduktif mungkin."

Persoalan yang muncul adalah, sementara kepemimpinan di dunia sekuler terus berkembang sesuai dengan kebutuhan zaman, apakah gereja harus mengadopsi model kepemimpinan sekuler? Padahal masih menurut Myron Rush, "Filosofi manajemen sekular sering kali terlalu bersifat manusiawi dan duniawi. Kekuatan dan kekuasaan dipandang sebagai cara untuk memanipulasi, memanfaatkan dan mengendalikan orang."3 Kondisi seperti ini tentu bertentangan dengan nilai-nilai kepemimpinan rohani.

Namun demikian menurut penulis, perlu juga digaris bawahi bahwa bila gereja mengabaikan kepemimpinan sekuler dalam pelayanannya berarti tidak memanfaatkan fasilitas ilmu pengetahuan bagi pekerjaan Tuhan. Sehingga menurut penulis, dalam konteks kepemimpinan gembala supaya berlangsung secara tepat guna dan berdasarkan prinsip "all truth is God's Truth“4 diperlukan suatu integrasi disiplin ilmu antara kepemimpinan rohani dengan kepemimpinan sekuler.

\footnotetext{
${ }^{2}$ Myron Rush, Manajemen Menurut Pandangan Alkitab (Malang : Gandum Mas,2002), 10.
}

${ }^{3}$ Myron Rush, Manajemen Menurut Pandangan Alkitab (Malang : Gandum Mas,2002), 10.

${ }^{4}$ Semua kebenaran adalah kebenaran Allah, pernyataan yang dapat dipahami berdasarkan pemahaman bahwa wahyu Allah dibagi menjadi dua : Pertama, wahyu yang bersifat khusus. Wahyu khusus adalah penyataan Allah di dalam firman-Nya, melalui penyataan inilah manusia mengenal Allah yang sejati, memperoleh keselamatan di dalam dan melalui Tuhan Yesus Kristus. Kebenaran ini tidak bisa dikompromikan karena bersifat Absolut, dan ; Wahyu kedua, adalah penyataan Allah yang bersifat umum, berkenaan dengan alam semesta dan ilmu pengetahuan. Melalui alam semesta dan ilmu pengetahuan manusia bisa melakukan apa saja (Kej.1l:6), namun tidak bisa mengenal Allah yang sejati. Berdasarkan konteks sudut pandang manusia, di dalam penyataan umum inilah kebenaran bisa berasal dari berbagai aspek. Namun lebih dari itu pengertian all truth is God's Truth merupakan sudut pandang atau pemahaman Allah daripada manusia. 


\section{Rumusan Masalah}

Pertama, Apa yang dimaksud integrasi kepemimpinan rohani dan sekuler ? sekuler?

Kedua, Apa yang dimaksud gembala sebagai proses integrasi kepemimpinan rohani dan

\section{Tujuan Penulisan}

Pertama, Membahas integrasi kepemimpinan rohani dan sekuler. sekuler.

Kedua, Membahas kepemimpinan gembala sebagai proses integrasi kepemimpinan rohani dan

\section{Manfaat Penulisan}

Pertama, Memberikan paradigma baru tentang kepemimpinan gembala.

Kedua, Menjadi bahan kajian dalam proses kepemimpinan gembala bagi kemajuan pelayanan gereja.

\section{Definisi Istilah \\ Kepemimpinan}

Menurut Gary Yukl kepemimpinan adalah, "Proses untuk mempengaruhi orang lain untuk memahami dan setuju dengan apa yang perlu dilakukan dan bagaimana tugas itu dilakukan secara efektif, serta proses untuk memfasilitasi upaya individu dan kolektif untuk mencapai tujuan bersama."

\section{Gembala}

Berdasarkan Ensiklopedi Alkitab Masa Kini, ada dua macam gembala dalam Alkitab: "Pertama, orang yang menggembalakan ternak; Kedua, orang yang mengasuh dan membina manusia, yaitu gembala yang bersifat ilahi maupun fana. Kata Ibrani dalam bentuk partisipium ialah ro'eh, kata Yunani poimen.."

\section{Integrasi}

Kamus Besar Bahasa Indonesia memberikan definisi kajian :"Pembauran hingga menjadi kesatuan yang utuh atau bulat."

\section{Kempemimpinan Rohani}

“Kata 'rohani' menunjukkan bahwa setiap manusia diciptakan dengan satu jiwa-satu dimensi rohani, disamping tubuh dan pikiran." "Kata rohani sering dipakai untuk kegiatan-kegiatan seperti ibadah dan doa dan pekerjaan yang berhubungan dengan gereja (keagamaan)." Jadi kepemimpinan rohani berarti suatu proses kepemimpinan yang terjadi dan dipraktekkan dengan melibatkan dimensi rohani.

\section{Kepemimpinan Sekuler}

Kamus Besar Bahasa Indonesia memberikan definisi sekuler,"Bersifat duniawi atau kebendaan(bukan bersifat keagamaan atau kerohanian)." Jadi kepemimpinan sekuler berarti suatu

${ }^{5}$ Gary Yukl, Kepemimpinan Dalam Organisasi (Jakarta: PT Indeks :2005), 8.

${ }^{6}$ Tim Penyunting, Ensiklopedi Alkitab Masa Kini Jilid A-L, RAS/MHS, Gembala ( Jakarta: Yayasan Komunikasi Bina kasih/OMF, 1992), 330.

${ }^{7}$ Ibid., 437.

${ }^{8}$ Alan E. Nelson, Spirituality and Leadership (Bandung: Yayasan Kalam Hidup, 2002) , 29.

${ }^{9}$ Tim Redaksi, Kamus Besar Bahasa Indonesia, Edisi Ketiga (Jakarta: Balai Pustaka,2001), 1015. 
proses kepemimpinan yang terjadi dan dipraktekkan oleh dunia secara umum yang tidak bersifat keagamaan atau kerohanian.

\section{Kajian Filosifis}

Kamus Besar Bahasa Indonesia memberikan definisi kajian : "Mengkaji: 1. Belajar ; mempelajari; 2. Memeriksa; menyelidiki; memikirkan (mempertimbangkan dsb); menguji; 3. menelaah."10 Sedangkan Filosofis : "Berdasarkan filsafat, 1. Pengetahuan dan penyelidikan dengan akal budi mengenai hakekat segala yang ada, sebab, asal dan hukumnya; 2 . Teori yang mendasari alam pikiran atau suatu kegiatan; 3. Ilmu yang berintikan logika, estetika, metafisika, dan epistemology; 4. Falsafah." Jadi, kajian filosofis berarti menelaah berdasarkan pengetahuan dan penyelidikan dengan akal budi mengenai hakekat, sebab, asal dan hukumnya.

\section{METODOLOGI PENELITIAN}

\section{Variabel dan Desain Penelitian}

Variabel yang diteliti dalam penelitian ini adalah: 1. Integrasi kepemimpinan rohani dan sekuler; 2. Gembala sebagai proses integrasi kepemimpinan rohani dan sekuler; 3. Kontribusi kepemimpinan gembala sebagai proses integrasi kepemimpinan rohani dan sekuler bagi pelayanan gereja.

\section{Sumber/Materi Data}

Dalam melaksanakan penelitian, peneliti menggunakan buku yang ada di perpustakaan STT Jaffray, pribadi, media, dan sumber-sumber dari internet.

\section{Tehnik Pengumpulan Data}

Penelitian ini menggunakan tehnik pengumpulan data yaitu literatur atau penyelidikan terhadap buku-buku dan tulisan-tulisan yang berkaitan dengan karya ilmiah. Secara khusus menggunakan buku-buku kepemimpinan, teologi, dan penggembalaan. Beberapa buku tersebut antara lain:

\section{Teologi dan Filsafat:}

Barth, Marie Claire. dan B. A. Pareira, Tafsiran Kitab Mazmur 1-72. Jakarta: BPK Gunung Mulia, 1999; Holmes, Arthur F. Segala Kebenaran adalah Kebenaran Allah. Surabaya: Penerbit Momentum, 200; Holmes, Tjaard G. dan E.Gerrit Singgih, Teologi dan Praksis Pastoral, Antologi Teologi Kristen. Yogyakarta: Kanisius,1997; Little,Paul E. Akal dan Kekristenan. Bandung: Yayasan Kalam Hidup, 1999; Nash, Ronald H. Konflik Wawasan Dunia. Surabaya, Penerbit Momentuk, 2000; Bakker, Anton. dan Drs.Achmad Charris Zubair, Metodologi Penelitian Filsafat. Yogyakarta : Penerbit Kanisius, 1994.

\section{Buku penggembalaan:}

Barna, Georga. Memasarkan Gereja, Bandung: Yayasan Kalam Hidup, 1993; Barkclay, William. Injil Yohanes Pasal 8-21. Jakarta: PT BPK Gunung Mulia, 2003; Conner, Kevin J. Jemaat Dalam Perjanjian Baru. Malang: Penerbit Gandum Mas, 2004; Jenson, Ron. dan Jim Stevens, Dinamika Pertumbuhan Gereja. Jakarta: Gandum Mas, 1996; Lawrence, Bill. Menggembalakan Dengan Hati. Yogyakarta: Andi Offset, 2004; Gerrit Singgih, Emanuel. Reformasi dan Transformasi Pelayanan Gereja Menyongsong Abad ke 2l. Yogyakarta: Penerbit Kanisius, 1997; Leigh, Ronald W. Melayani dengan Efektif. Jakarta: BPK Gunung Mulia, 1993;

\footnotetext{
${ }^{10}$ Tim Redaksi, Kamus Besar Bahasa Indonesia, Edisi Ketiga (Jakarta :Balai Pustaka,200), 491.

${ }^{11}$ Ibid., 317.
} 


\section{Buku kepemimpinan Rohani:}

Barna, George. Leaders on Leadership; Malang: Leader on Leadership, 1997; Blackaby, Henry dan Richard Blackaby, Kepemimpinan Rohani. Jakarta: Gospel, 2009; Blanchard, Ken. dan Phil Hodges, Lead Like Jesus. Tangerang: Agromedia Pustaka, 2007; Maxwell, John C. Jadilah Orang yang Berorientasi Manusia. Batam Centre: Interaksa, 199; Myron, Rush. Manajemen Menurut Pandangan Alkitab. Malang: Gandum Mas, 2002; Nelson, Alan E. Spirituality and Leadership. Bandung: Yayasan Kalam Hidup, 2002; Tomatala, Yakob. Kepemimpinan Yang Dinamis. Jakarta : YT Leadership Foundation; Malang: Penerbit Gandum Mas, 1997; Tomatala, Yakob. Kepemimpinan Kristen. Jakarta: YT Leadership Foundation, 2002.

\section{Kepemimpinan Sekuler:}

Frances Hesselbein, Frances. Menjadi Pemimpin Masa Depan. Yogyakarta: Pustaka Pelajar, 2007; Hesselbein, Frances. and Marshal Goldsmith, The Leader of The Future; Usman A.Gani, Pemimpin integrator. Jakarta: Penerbit PT Elex Media Komputindo, 2008; Robbins, Stephen P. Perilaku Organisasi. Jakarta: PT. Prenhallindo, 1996; Yukl, Gary. Kepemimpinan Dalam Organisasi. Jakarta: PT Indeks: 2005.

Data-data yang digunakan terdiri atas data primer dan sekunder. Data primer penelitian ini adalah semua gagasan yang ditulis oleh tokohnya sendiri yang berkaitan dengan masalah yang dikaji, sementara data sekundernya adalah segala informasi dari berbagai karya yang ditulis orang lain yang berkaitan dengan tema penelitian, baik berupa buku maupun artikel-artikel.

\section{Tehnik Analisa Data}

Penelitian ini bersifat library research, yang di dasarkan atas data dan informasi dari leteratur-literatur. Karena data bersifat teks maka pendekatan yang digunakan adalah hermeneutik. Prosedur penganalisaan data menggunakan model penelitian komparatif. Kemudian untuk menghasilkan konsepsi yang menyeluruh diadakan evaluasi. Sedang bentuk penelitiannya adalah induksi dan deduksi.

\section{Hermeneutik.}

Hermeneutik “yang secara harafiah dapat diartikan sebagai 'penafsiran' atau interprestasi" 12 merupakan "proses mengubah sesuatu atau situasi ketidaktahuan menjadi mengerti." ${ }^{\text {"3 }}$ Pendekatan ini digunakan untuk menemukan makna terdalam atau nilai dari teks atau kalimat. Sedangkan materi pembahasannya seperti dikatakan Muhsin Hariyanto, "Meliputi dua sektor yaitu pertama perenungan filsofis tentang dasar-dasar dan syarat-syarat konstruksi pemahaman. Kedua pemahaman dan penafsiran teks itu sendiri melalui media bahasa." ${ }^{14}$ Seperti apa dasar-dasar filosofis integrasi kepemimpinan rohani dan sekuler? Dan bagaimana konsep kepemimpinan gembala sebagai hasil proses kepemimpinan rohani dan sekuler?

\section{Komparatif.}

Prosedur penganalisaan data menggunakan model penelitian komparatif dari Dr. Anton Bakker dan Drs. Achmad Charris Zubair dalam bukunya "Metodologi Penelitian Filsafat :"15 Pertama. Membandingkan pandangan-pandangan, baik yang sama atau berbeda, mendukung maupun bertentangan tentang bahasan "Integrasi Kepemimpinan Rohani dan Sekuler". Kedua. Perbandingan ini merupakan perbandingan pandangan tokoh-tokoh mengenai kesamaan atau perbedaan dalam hakekat, norma dan argumentasi tentang integrasi kepemimpinan rohani dan sekuler . Ketiga. Supaya perbandingan relevan maka pandangan-pandangan tersebut adalah representatif bagi suatu cara

\footnotetext{
${ }^{12}$ E.Sumaryono, Hermeneutik, Sebuah Metode Filsafat (Yogyakarta : Penerbit Kanisius, 1999), 23.

${ }^{13}$ Ibid, 24

${ }^{14}$ Muhsin Hariyanto, "Hermeneutik : Sebuah Pengantar" Fai.elcom.umy.ac.id ; diakses tanggal 1 April 2009 ; tersedia di http://fai.elcom.umy.ac.id/mod/forum/discuss.php?d=89

15 Dr.Anton Bakker dan Drs.Achmad Charris Zubair, Metodologi Penelitian Filsafat (Yogyakarta : Penerbit Kanisius, 1994), 83-88.
} 
berpikir. Dalam pikiran mereka ditemukan satu atau beberapa masalah bersama yang mereka telaah, dan masalah itu bagi mereka berkedudukan sangat sentral.

Evaluasi.

Evaluasi terhadap setiap atau keseluruhan pandangan digunakan untuk menganalisa secara tajam keterbatasan, kelebihan, perbedaan dan kesamaan pandanganpandangan yang ada. Hal ini dilakukan untuk menghasilkan konsepsi yang lebih menyeluruh dan bernilai untuk terbentuknya perbandingan yang lebih luas, perspektif baru dan pemecahan masalah yang lebih umum bagi semuanya.

\section{Induksi dan Diduksi.}

Melalui penelitian induksi dan diduksi dilakukan penelitian secara teliti setiap konsep dan pandangan-pandangan yang ada dan dibentuk suatu sintesa pikiran yang meliputi semua unsur secara seimbang (induksi). Pemahaman yang diperoleh dipergunakan untuk lebih mengerti setiap detail dalam pandangan itu (deduksi).

Berkenaan dengan keterlibatan pribadi, penulis berusaha turut memikirkan dan melihat visi itu, tanpa kehilangan objektivitasnya. Dalam rangka komparasi antara pandangan - pandangan, secara khusus diperlihatkan detail-detail yang berhubungan dengan tema atau masalah yang menjadi pokok pengkajian.

\section{ANALISIS DATA DAN INTERAKSI \\ Analisis Kepemimpinan Gembala \\ Sebagai Proses Integrasi Kepemimpinan Rohani dan Sekuler}

\section{Pandang Para Tokoh Kepemimpinan Berdasarkan Tipologi Brian Eck}

Untuk mendapat pemahaman yang lebih komprehensif tentang integrasi kepemimpinan rohani dan sekuler, penulis mengemukakan pemikiran dari beberapa tokoh kepemimpinan Kristen berdasarkan tipologi Brian Eck. Salah satu pertimbangan tentang pemilihan nama-nama tokoh tersebut paling tidak diakui kepemimpinannya khususnya dalam dunia Kristen, dan berdasarkan tingkat keterkaitan buku-buku mereka dengan proses integrasi, serta adanya referensi tentang pemikiran tokoh tersebut dari tokoh lain. Aspek utama yang menjadi pembahasan adalah bagaimana upaya mereka mengkonsepkan kepemimpinan rohani dalam kerangka keterkaitan antara kepemimpinan rohani dan sekuler.

\section{Paradigma Non-Integrasi}

Henry $^{16}$ dan Richard Blackaby ${ }^{17}$

Henry dan Richard Blackaby berpendapat bahwa meskipun kepemimpinan rohani dan kepemimpinan sekuler dalam area-area tertentu memiliki kesamaan, namun kedua kepemimpinan tersebut memiliki sifat yang berbeda. Sebab itu kepemimpinan rohani dan sekuler tidak bisa digabungkan begitu saja. Argumentasi Henry dan Richard Blackaby:

\footnotetext{
${ }^{16}$ Henry Blackaby direktur misi di Vancouver, Kanada, Konsultan istimewa untuk pemimpin dari North American Mission Board, International Mission Board, dan LifeWay Christian Resources dari Southern Baptist Convention dan pemimpin Henry Blackaby Ministries. Penulis buku Experiencing Go : Knowing and Doing the Will of God, Experiencing God Day-by-Day, The Man God Uses, Created to Be God's Friend dan The Ways of God

${ }_{17}$ Richard Blackaby adalah anak sulung dari Henry dan Marilynn Blackaby, Rektor Southern Babtist Seminary di Cochrane, Kanada. Bersama ayahnya menulih buku : When God Speaks, God's Invitation, CrossSeeks, Experiencing God Day-by-Day, dan The Experience.
} 
Kepemimpinan rohani tidak sama dengan kepemimpinan pada umumnya. Meskipun kepemimpinan rohani juga meliputi banyak prinsip yang sama seperti kepemimpinan umum, tetapi kepemimpinan rohani punya sifat-sifat berbeda yang khusus yang harus dipahami dan dipraktikkan jika seorang pemimpin rohani ingin berhasil. ${ }^{18}$

Pada sisi yang lain Henry dan Richard Blackaby mengakui bahwa kepemimpinan sekuler bisa memberikan kontribusi kepada kepemimpinan rohani, namun demikian menurut Henry dan Richard Blackaby bila kepemimpinan rohani semata-mata mengikuti kepemimpinan sekuler tidak akan bisa maksimal:

Pemimpin sekuler dan rohani dapat memakai metode yang serupa, tetapi ada dimensi kepemimpinan rohani yang tidak ada dalam seorang pemimpin sekuler. Pemimpin rohani yang hanya sekedar mengikuti metode sekuler mungkin mengalami suatu tingkat keberhasilan tertentu, tetapi mereka tidak akan mencapai tingkat kepemimpinan lebih tinggi yang sebetulnya bisa mereka capai sebagai pemimpin rohani sejati. ${ }^{19}$

Bagi Henry dan Richard Blackaby hanya melalui kepemimpinan Allah-lah kepemimpinan rohani menjadi maksimal, sebab "ketika mereka menerapkan metode kepemimpinan Allah, mereka memperoleh hasil-hasil yang luar biasa." ${ }^{20}$

Lebih jauh dari itu Henry dan Richard Blackaby beranggapan bahwa dalam kepemimpinan seharusnya dunia rohani dan sekuler tidak bisa dipisahkan. Sehingga kepemimpinan rohani harus juga diterapkan dalam kepemimpinan sekuler:

Setiap orang, baik orang Kristen maupun non-Kristen, adalah manusia rohani dengan kebutuhan rohani. Para pegawai, pelanggan, dan dewan direksi perusahaan semuanya punya kebutuhan rohani yang Allah ingin penuhi hamba-hamba-Nya di tempat kerja mereka. Allah juga pencipta hubungan antar manusia. Dia telah menetapkan hukum-hukum tentang hubungan antar manusia yang tidak berubah dengan berlalunya waktu. Melanggar prinsip hubungan antar manusia yang telah ditetapkan Allah di tempat kerja berarti mengundang malapetaka. Yesus Kristus adalah Tuhan dari semua pemercaya baik mereka yang ada di gereja maupun di tempat kerja. Kerajaan Allah adalah, sebenarnya, pemerintahan Allah dalam setiap aspek kehidupan manusia, termasuk gereja, rumah tangga, tempat kerja, dan lingkungan tetangga. Mengabaikan kebenaran-kebenaran ini ketika memasuki dunia bisnis atau arena politik berarti membahayakan diri sendiri. ${ }^{21}$

Berdasarkan landasan berpikir tersebut, maka Henry dan Richard Blackaby menganggap bahwa kepemimpinan Kristen lebih baik dari kepemimpinan sekuler. Sebab itu cara kepemimpinan rohani harus diterapkan pada seluruh aspek kehidupan manusia:

Para pemimpin Kristen yang mengenal Allah dan yang tahu cara memimpin secara Kristiani, secara fenomenal akan jauh lebih efektif dibandingkan pemimpin yang paling terampil dan mampu yang memimpin tanpa Allah. Kepemimpinan rohani tidak terbatas untuk gembala dan misionaris saja. Kepemimpinan rohani adalah tanggung jawab semua orang Kristen yang Allah ingin pakai untuk membuat perbedaan di dunia mereka. Tantangan bagi pemimpin masa kini adalah untuk dapat mengenali perbedaan antara model kepemimpinan terbaru yang ngetren saat ini dan kebenaran yang kekal yang diterapkan oleh Allah. ${ }^{22}$

Pada akhirnya Henry dan Richard Blackaby berkesimpulan bahwa "banyak dari prinsip kepemimpinan 'modern' yang saat ini dipromosikan sebenarnya adalah prinsip alkitabiah yang telah diperintahkan Allah sepanjang sejarah." ${ }^{23}$ Karena itu menurut Henry dan Richard Blackaby untuk menjadi pemimpin rohani yang efektif ialah dengan jalan menyelidiki Alkitab dengan tokoh-tokoh kepemimpinannya," Kami telah meneliti Alkitab, dan kami telah meneliti kehidupan pemimpin yang efektif dalam terang Firman

\footnotetext{
${ }^{18}$ Henry dan Richard Blackaby, Kepemimpinan Rohani (Jakarta : Gospel, 2009), 38.

${ }^{19}$ Ibid., 7.

${ }^{20}$ Ibid., 6 .

${ }^{21}$ Ibid., 29.

${ }^{22}$ Ibid., 30

${ }^{23}$ Ibid., 24
} 
Allah. Dengan berbuat begitu, kami telah menemukan beberapa prinsip alkitabiah yang jelas yang membuat seorang pemimpin efektif." 24

Stacy T.Rinehart. ${ }^{25}$

Bagi Stacy T. Rinehart kepemimpinan rohani dan sekuler berbeda, perbedaan ini terutama terletak kepada nilai, asumsi dan prinsip yang melandasinya, bahwa "inti keyakinan kita mengenai kepemimpinan akan menentukan apakah model kepemimpinan yang berkuasa atau penghambaan yang paling lajim." ${ }^{26}$ Sehingga menurut Stacy $\mathrm{T}$. Rinehart," Sebelum kita mampu mempertimbangkan model kepemimpinan kita pada tingkat nilai-nilai, asumsi dan prinsip yang terdapat di dalamnya, kita tidak dapat membedakan apakah sejauh ini kepemimpinan kita berasal dari dasar kekuasaan atau hamba." ${ }^{27}$

Stacy T.Rinehart mengemukakan bahwa, "Kepemimpinan pelayan bersumber dari serangkaian nilai, asumsi dan prinsip yang bertentangan dengan dunia sekuler." ${ }^{28}$ Namun demikian Stacy percaya bahwa kepemimpinan sekuler bisa memberikan sumbangsih kepada kepemimpinan rohani, asal tidak begitu saja diterapkan dalam kepemimpinan rohani. Ini bisa dilihat dari apa yang dikatakannya," Saya tidak berkata bahwa filosofi kepemimpinan sekuler tidak menawarkan manfaat. Tetapi kita tampaknya mengadopsi beberapa filosofi tersebut secara keseluruhan, tanpa kritik yang penting". ${ }^{29}$

Stacy T. Rinehart mengakui bahwa, "Kristus tidak pernah meletakkan suatu cetak biru yang jelas mengenai bagaimana memimpin." ${ }^{30}$ Walaupun demikian Stacy T. Rinehart beranggapan bahwa firman Tuhan memberikan nilai-nilai kepemimpinan:

Tetapi jika kita melihat kepada Allah Tritunggal, kita melihat bahwa Dia telah memberikan contoh kepemimpinan untuk kita. Nilai-nilai dan prinsip kepemimpinan-Nya tersebar di dalam firman Tuhan. Walaupun Tuhan tidak memberikan kepada kita suatu formula atau resep kaku, Dia tidak membiarkan kita merapa-raba dalam gelap atau menunggu seminar manajemen baru yang berikutnya untuk memberikan arah kepada kita. ${ }^{31}$

Menurut Stacy "daripada berpedoman pada budaya yang ada di sekitar kita, kita seharusnya menarik manfaat dari apa yang membuat kepemimpinan rohani sungguh berfokus kepada Allah" ${ }^{32}$. Menurut Stacy kepemimpinan rohani harus dibangun berdasarkan apa yang teladankan dan ajarkan "kepemimpinan pelayan bukanlah cita-cita yang mustahil dalam masa sekarang. Sebaliknya, prinsip itu seharusnya menjadi landasan batu penjuru bagi pemikiran kita mengenai kepemimpinan rohani. Kristus hidup, mengajar dan memberikan contoh kepada kita, dan ini adalah hal yang sungguh istimewa sebagai orang percaya". ${ }^{33}$

\section{Paradigma Integrasi Manipulatif}

John C. Maxwell ${ }^{34}$.

Tidak diragukan lagi bahwa John C. Maxwell adalah ahli kepemimpinan, bukan saja kepemimpinan Kristen tetapi juga dunia sekuler. Dalam hubungan kepemimpinan Kristen dan sekuler John C. Maxwell lebih mengedepankan arti nilai-nilai yang

\footnotetext{
${ }^{24}$ Ibid., 6.

${ }^{25}$ Stacy T.Rinehart adalah wakil ketua The Navigators, Doktor Teologi dari Trinity Evangelical Devinity School.

${ }^{26}$ Ibid., 30.

${ }^{27}$ Henry dan Richard Blackaby, Kepemimpinan Rohani ( Jakarta : Gospel, 2009), 30.

${ }^{28}$ Stacy T.Rinehart, Upside Down, Paradoks Kepemimpinan Pelayan (Jakarta :Penerbit Immanuel, 2002),

38.

${ }^{29}$ Ibid., 34.

${ }^{30}$ Ibid., 92.

${ }^{31}$ Ibid. 92.

${ }^{32}$ Ibid., 28.

${ }^{33}$ Stacy T.Rinehart, Upside Down, Paradoks Kepemimpinan Pelayan (Jakarta :Penerbit Immanuel, 2002),

28.

${ }^{34}$ John Maxwell dikenal sebagai ahli kepemimpinan Amerika. Selain mendirikan Injoy Stewardship Services, melalui EQUIP ia melatih para pemimpin di dunia. Sebagai penulis terlaris menurut Majalah New York Times, ia telah menulis lebih dari 30 buku.
} 
melandasinya, selanjutnya nilai-nilai itu mentransformasi kepemimpinan sekuler. Hal ini dapat dilihat dari tiga pertanyaan yang diajukan oleh John C. Maxwell," Mengapa saya melakukan ini?, bagaimana seharusnya itu dilakukan? dan bilamana seharusnya saya melakukannya ${ }^{35}$ Dan John C. Maxwell menyatakan bahwa standar nilai kepemimpinan Kristen berbeda dengan dunia," Kita tidak dinilai dengan standar yang sama dengan standar dunia. ${ }^{36}$

Bagi John C. Maxwell kepemimpinan dilandasi berdasarkan nilai-nilai Kristen. Sistem nilai yang dibangun itu akan berfungsi sebagai filter dalam melihat kehidupan. Dia menegaskan, "Orang yang punya integritas adalah orang yang telah menetapkan satu sistem nilai yang digunakan untuk menilai semua kehidupan. Sistem nilai ditetapkan oleh jalan seseorang dengan Tuhan." ${ }^{37}$ John C. Maxwell menguraikan empat bidang yang merupakan hasil dari nilai-nilai yang dipraktekkan dalam hidup. Melalui nilai-nilai tersebut terungkap siapa sebenarnya orang tersebut, di dalam gereja maupun di luar. Empat bidang itu meliputi:

Watak, apakah saya membuat keputusan berdasarkan apa yang benar atau apa yang paling mudah diterima? Apakah saya pemimpin atau pengikut; Perubahan, apakah saya mengubah kepribadian, bicara, atau tindakan saya sesuai dengan orang yang bersama saya?; Penghargaan, kalau saya melakukan sesuatu untuk Tuhan, apakah mereka melihat saya atau Tuhan saya? Dan apakah saya mempedulikan siapa yang akan menerima penghargaan? dan; Saluran, Apakah Tuhan bekerja melalui saya untuk menyentuh orang lain? Kalau kehidupan orang lain tidak berubah sebagai hasil kehidupan saya, ini petunjuk yang baik bahwa citra yang saya bangun adalah citra saya sendiri, bukan citra Tuhan. Hanya kalau Anda terbuka, jujur, transparan, dan rentan terhadap orang lain sajalah Tuhan bisa memanfaatkan Anda untuk mengubah orang lain. ${ }^{38}$

Yakob Tomatala ${ }^{39}$.

Yakob Tomatala menganggab kepemimpinan merupakan gejala universal, Bahwa "kepemimpin selalu ada pada setiap budaya dari segala bangsa di seluruh dunia." Menurutnya, "Kepemimpinan Kristen pada dasarnya sama dengan kepemimpinan umum lainnya." Hal yang membedakan kepemimpinan Kristen dengan yang umum adalah adanya campur Tangan Allah:

Di dalamnya oleh campur tangan Allah, Ia memanggil bagi diri-Nya seorang pemimpin (dengan kapasitas penuh) untuk memimpin umat-Nya (yang mengelompokkan diri dalam suatu institusi/organisasi) guna mencapai tujuan Allah (yang membawa keuntungan bagi pemimpin, bawahan, dan lingkungan hidup) bagi serta melalui umat-Nya, untuk kejayaan kerajaan-Nya. ${ }^{42}$

Pemikiran Yakob Tomatala tentang hubungan kepemimpinan Kristen dengan sekuler dapat dilihat dari pandangannya tentang "Relevansi Penerapan Kepemimpinan Kristen dalam konteks". ${ }^{43}$ Dalam tulisan tersebut, menurut Yakob Tomatala kepemimpinan Kristen bersifat transkultur dan reflektis-kritis berdasarkan nilai-nilai Kristen:

${ }^{35}$ John C.Maxwell, Jadilah Orang yang Berorientasi Manusia ( Batam Centre :Interaksa, 1999), 146.

${ }^{36}$ Ibid.,139.

${ }^{37}$ John C.Maxwell, Jadilah Orang yang Berorientasi Manusia ( Batam Centre :Interaksa, 1999), 139.

${ }^{38}$ Ibid., 149-150.

${ }^{39}$ Pengajar, penulis buku dan pernah menjabat sebagai Rektor Institut Filsafat Theologi dan Kepemimpinan Jaffray Jakarta dan Ketua Umum Sinode Gereja Kemah Injil Indonesia (2001-2006)

${ }^{40}$ Yakob Tomatala, Kepemimpinan Yang Dinamis ( Jakarta : YT Leadership Foundation ; Malang :

Penerbit Gandum Mas, 1997), 2.

${ }^{41}$ Ibid., 7.

${ }^{42}$ Yakob Tomatala, Kepemimpinan Yang Dinamis ( Jakarta : YT Leadership Foundation ; Malang : Penerbit Gandum Mas, 1997), 12-13.

${ }^{43}$ Ibid., 81. 
Diawali dengan penegasan bahwa model kepemimpinan Kristen yang akan diterapkan dalam konteks disini bersifat transkultur dengan dinamika yang reflekstis-kritis. Transkultur mengandung prinsipprinsip dan norma-norma kepemimpinan yang dapat diterapkan secara universal dan inklusif bagi setiap/semua budaya. Pada sisi lain, dinamikanya yang reflektis-kritis menjelaskan adanya dua sisi penting yang harus diperhatikan dalam penerapan model dimaksud. Pertama, bersifat kritis yang beranjak dari falsafah kepemimpinan Alkitab sebagai landasan berpijak bagi kepemimpinan gereja dalam konteks. Di sini kepemimpinan Kristen yang reflektif ini harus menjadi landasan berpijak untuk menerangi konteks di mana kepemimpinan Kristen diterapkan. Kedua, mengingat kepemimpinan pada umumnya adalah ilmu dan seni yang lugas serta terbuka, maka refleksi dari model kepemimpinan ini haruslah bersifat selektif-akomodatif terhadap elemen-elemen kepemimpinan dalam setiap budaya. Pendekatan ini berperan memilah dan memilih unsur kepemimpinan kontekstual (bentuk, arti, fungsi) yang dapat dipakai untuk menerapkan kepemimpinan Kristen dalam gereja pada suatu konteks. ${ }^{44}$

\section{Paradigma Integrasi Non-Manipulatif}

Ken Blanchard ${ }^{45}$ dan Phil Hodges ${ }^{46}$.

Menurut Ken Blanchard dan Phil Hodges kepemimpinan Kristen adalah tindakan pelayanan, ini bukan merupakan pilihan tetapi keharusan, dan kepemimpinan pelayan harus melandasi motif, cara dan tujuan. Penjelasan Ken Blanchard dan Phil Hodges," Bagi para pengikut Yesus, kepemimpinan sebagai tindakan pelayanan bukanlah pilihan. Itu adalah mandat atau perintah. Kepemimpinan yang melayani harus menjadi stateman hidup dari mereka yang tinggal dalam Kristus, cara kita memperlakukan satu sama lain, dan cara kita memperlihatkan cinta Kristus kepada seluruh dunia". ${ }^{47}$

Ken Blanchard dan Phil Hodges menemukan bahwa "dalam diri Yesus Kristus orang Kristen memiliki lebih banyak hal daripada sekadar seorang pemimpin spiritual; Kita memiliki satu model kepemimpinan yang praktis dan efektif untuk semua organisasi, untuk semua orang dan untuk semua situasi." ${ }^{48}$ Menurut mereka, "Memimpin seperti Yesus merupakan satu sarana yang membantu Anda mencapai Allah mengatasi sekat spiritual dari kehidupan spiritual pribadi Anda dan untuk memberi Dia bebas masuk dalam seluruh tindakan Anda sehari-hari dan hubungan sehari-hari, khususnya peran-peran kepemimpinan Anda". 49

Mengenai hubungan kepemimpinan seperti Yesus dengan konteks kepemimpinan jaman sekarang Ken Blanchard dan Phil Hodges melihatnya dalam dua aspek: Transformasi dan internalisasi empat ranah kepemimpinan," Ada dua aspek dari memimpin seperti Yesus. Pertama, adalah pemahaman bahwa memimpin seperti Yesus

${ }^{44}$ Yakob Tomatala, Kepemimpinan Yang Dinamis ( Jakarta : YT Leadership Foundation ; Malang : Penerbit Gandum Mas, 1997), 81-82.

${ }^{45}$ Ken Blanchard menulis lebih dari 40 buku manajemen dan kepemimpinan, pemimpin pelayanan rohani di The Ken Blanchard Companies. Bersama Phil Hodges, ia mendirikan Lead Like Jesus, sebuah lembaga pelayanan yang dibentuk pada tahun 1999 untuk membantu para pemimpin menjalankan hidup yang mengeksporasi dan mengekpresikan prinsip kepemimpinan Yesus.

${ }^{46}$ Phil Hodges melayani sebagai seorang yang bergelut di bidang sumber daya manusia dan manajer hubungan industri di sebuah perusahaan Amerika selama 36 tahun dan sebagai anggota dan ketua dewan majelis gereja lokal selama 10 tahun. Pada tahun 1999 bersama Ken Blanchard ia mendirikan Lead Like Jesus.

${ }^{47}$ Ken Blanchard dan Phil Hodges, Lead Like Jesus ( Tangerang : Agromedia Pustaka, 2007), 15.

${ }^{48}$ Ibid., XX.

${ }^{49}$ Ken Blanchard dan Phil Hodges, Lead Like Jesus ( Tangerang : Agromedia Pustaka, 2007), XXI. 
merupakan suatu perjalanan transformasi ${ }^{50}$; Kedua, dan paling penting, adalah belajar menginternalisasi "empat ranah" ${ }^{\text {"1 }}$ atau bidang kepemimpinan". 52

Hal prinsip bagi pemimpin menurut Ken Blanchard dan Phil Hodges adalah harus menjawab dua pertanyaan penting, "Pertama, milik siapakah aku?, Kedua, Siapakah aku? Aspek pertama "berurusan dengan memilih otoritas dan pendengar primer bagi hidup Anda. Dengan kata lain, siapa yang coba Anda gembirakan ? pemimpin selalu menunjukkan milik siapakah mereka dengan cara bagaimana mereka mendefinisikan keberhasilan dalam dunia dewasa ini. Mereka mengira keberhasilan harus berurusan dengan kekuasaan dan posisi di dunia, dan juga kinerja dan opini dari orang lain" ${ }^{\text {"5 }}$; Aspek kedua, "berurusan dengan tujuan hidup Anda? Apa yang Dia ingin lakukan melalui Anda? Kitab Suci mengajarkan bahwa keberhasilan sejati adalah terpenuhinya misi hidup yang Allah rencanakan melalui Anda. Keberhasilan Anda bergantung pada hubungan Anda dengan Kristus dan pada level kontrol dalam hal apa Anda membiarkan Allah masuk dalam hidup Anda. Apakah Anda bersedia menyerahkan seluruh diri anda kepada-Nya dan menjalani hidup Anda menurut kehendak-Nya, atau Anda mau menjalani hidup ini dengan cara Anda sendiri ?"55

\section{Robert K.Greenleaf. $^{56}$}

Robert K.Greenleaf adalah penggagas kepemimpinan pelayan ( Servant Leadership). Merunut Jan H. Rapar, gagasan kepemimpinan pelayan di mulai dalam pemikiran Greenleaf ketika mengikuti kuliah seorang profesor tua yang mengatakan:

There is new problem in our country. We are becoming a nation that is dominated by large institutions... Churches, business, goverments, labor unions, universities... and these big institutions are not serving us well. I hope that all of you will be concerned about this. Now you can do as I do, stand outside and criticize, bring pressure if you can, write and argue about it. All of this may do some good. But nothing of substance will happen unless there are people inside these institutions who are able to ( and want to) lead them into better performance for the public good. Some of you ought to make careers inside these big institutions anda become a force for good ... from the inside. ${ }^{57}$

Kemudian gagasan itu semakin kuat memperoleh bentuknya ketika Greenleaf membaca buku berjudul "Journey to the East" yang ditulis oleh Herman Hese, dan Greanleaf mengemukakan:

50 Memimpin seperti Yesus merupakan suatu siklus transformasi yang mulai dengan kepemimpinan personal dan kemudian bergerak memimpin orang lain dalam hubungan satu satu, kemudian memimpin satu tim atau kelompok, dan akhirnya, memimpin satu organisasi atau masyarakat. Kita tahu, rangkaian ini terjadi baik dalam kepemimpinan peran hidup maupun kepemimpinan organisasi. Ken Blanchard dan Phil Hodges, Lead Like Jesus ( Tangerang : Agromedia Pustaka, 2007), 25.

${ }^{51}$ Hati adalah mengenai motivasi, kepemimpinan pertama-tama merupakan tindakan atau urusan spiritual di dalam hati, Apakah Anda seorang pemimpin pelayan atau pemimpin yang melayani diri sendiri ; Kepala, memeriksa keyakinan dan teori Anda tentang memimpin dan memotivasi orang lain ; Tangan, Menyangkut penetapan tujuan yang jelas dan kemudian mengamati kinerjanya, yang diikuti dengan memuji kemajuan dan mengarahkan kembali perilaku yang tidak tepat, dan ; Kebiasaan, adalah cara bagaimana Anda membarui komitmen Anda sehari-hari sebagai seorang pemimpin untuk melayani, bukan dilayani.

${ }^{52}$ Ken Blanchard dan Phil Hodges, Lead Like Jesus ( Tangerang : Agromedia Pustaka, 2007), 24.

${ }^{53}$ Ibid., 26.

${ }^{54}$ Ken Blanchard dan Phil Hodges, Lead Like Jesus ( Tangerang : Agromedia Pustaka, 2007), 26.

${ }^{55}$ Ibid. 26.

${ }^{56}$ Robert K.Greenleaf pelopor kepemimpinan pelayan (Servant Leadership), menghabiskan 38 tahun dari hidupnya di perusahaan AT\&T, USA hingga ia pensiun sebagai Wakil Presiden untuk penelitian manajemen. Segera setelah pensiun ia mendirikan Centre for Applied Ethics pada tahun 1964, yang kemudian diubah menjadi Greenleaf Centre for Servant-Leadership pada tahun 1985. W.I.M Poli, Manajemen Perilaku Organisasi ( Makassar : Diktat Kuliah Kepemimpinan STT Jaffray, 2008).

${ }^{57}$ Jan H. Rapar," Mengembangkan Karakter Kepemimpinan Transformatif "Jahenra.blogspot.com ; diakses tanggal 29 Juli 2009; tersedia di http://jahenra.blogspot.com/2009/02/mengembangkan-karakterkepemimpinan.html. 
In this story we see a band of men on a mythical journes, probably also hesse's own journey. The central figure of the story is leo who accompanies the party as the servent who does their menial chores, but who also sustains them with his spirit and his song. He is a person of extraordinary presence. All goes well until leo dissapers. Then the group falls into disarray and the journey is abondened. The cannot make it without the servant Leo. The narrator, one of the party, after some years of wandering finds Leo and is taken into the order that had sponsored the journey. There he discoveres that Leo, whom he had known first as servant, was in fact the titular head of the order, its guiding spirit, a great and noble leader. ${ }^{58}$

Pemimpin sejati bagi Greenleaf adalah," seorang yang memimpin (mempengaruhi orang lain) lewat perbuatannya yang memberi inspirasi bagi orang lain dan mendorong orang lain untuk bertindak demi mencapai tujuan yang hendak dicapai." ${ }^{59}$ Secara lengkap uraian Greenleaf tentang kepemimpinan pelayan dikemukakan kembali oleh W.I.M Poli :

The Servant-leader is servant first. It begins with the natural feeling that one wants to serve. Then conscious choice brings one to aspire to lead. The best test is : do those served grow as persons: do they, while being served, become healthier, wiser, freer, more autonomous, more likely themselves to become servants? Anda, what is the effect on the least privileged ini society; will benefit, or, at least, not be further deprived ? ${ }^{60}$

Larry Spears melalui penelitian terhadap tulisan Greenleaf menemukan sepuluh karakteristik utama dari pemimpin pelayan, antara lain ${ }^{61}$ : 1. Mendengarkan. Mempunyai komitmen untuk mendengarkan orang lain; 2. Emphati.Turut merasakan atau memahami apa yang dialami oleh orang lain; 3. Menyembuhkan. Menyembuhkan atau memulihkan diri sendiri atau orang lain bila ada masalah, patah semangat atau mengalami penderitaan emosional; 4. Kesadaran. Memiliki kesadaran atau kepekaan terhadap situasi, kondisi lingkungan serta isu-isu seputar etika dan nilai. Pemimpin pelayan memiliki kemampuan melihat secara komprehensif dan integral; 5. Pendekatan. Memiliki kemampuan menggunakan pendekatan personal daripada penggunaan otoritas atau wewenangan kekuasaan; 6. Berpikir secara konseptual. Memiliki pandangan yang menyeluruh dengan mengkonsepkan ide kemudian diaplikasikan atau melihat permasalahan dengan baik untuk dicari jalan keluarnya; 7. Memiki pandangan ke depan. Mampu melihat situasi dan jauh berpandangan ke depan untuk mengantisipasi segala kemungkinan yang ada; 8 . Penatalayanan. Memiliki komitmen untuk saling melayani. Keterbukaan dan pendekatan lebih baik daripada kontrol; 9. Memiliki komitmen untu membuat orang lain bertumbuh. Pertumbuhan orang lain merupakan bagian penting dari proses kepemimpinan. Melalui hal ini mereka semakin dapat memberikan kontribusi dengan baik, dan; 10. Membangun komunitas. Membangun kelompok atau komunitas dimana mereka dapat berelasi dengan orang-orang dimana mereka bekerja.

Alan E.Nelson ${ }^{62}$.

Alan E. Nelson mendefinisikan kepemimpinan rohani sebagai, "orang-orang yang secara rohani selaras dengan Allah dan hidup mengikuti tuntunan-Nya, dan menjadi orang yang berpengaruh melalui bakat serta kecakapannya." ${ }^{63}$ Definisi Alan E. Nelson

${ }^{58}$ Jan H. Rapar," Mengembangkan Karakter Kepemimpinan Transformatif “Jahenra.blogspot.com ; diakses tanggal 29 Juli 2009; tersedia di http://jahenra.blogspot.com/2009/02/mengembangkan-karakterkepemimpinan.html.

${ }^{59}$ Ibid.

${ }^{60}$ W.I.M Poli, Manajemen Perilaku Organisasi ( Makassar :Diktat Kuliah Kepemimpinan STT Jaffray, 2008).

${ }^{61}$ Larry Spears, "Practicing Servant - Leadership" Leader to Leader, 34 (Fall 2004) 7-11

${ }^{62}$ Alan E. Nelson, pendiri dan gembala senior dari Scottsdale Family Church di Arizona, meraih gelar doktor dalam bidang kepemimpinan dari Universitas San Diago. Ia juga kolumnis untuk majalah Rev., dan juga penulis dari sejumlah buku, di antaranya Embracing Brokenness (NavPress), My Own Worst Enemy, dan Leading Your Ministry. Alan dan istrinya, Nancy, dikaruniai tiga orang putra.

${ }^{63}$ Alan E. Nelson, Spirituality and Leadership (Bandung : Yayasan Kalam Hidup, 2002), 30. 
dalam konteks kepemimpinan menunjukkan bahwa kepemimpinan rohani merupakan penyatuan dari dua unsur yang berbeda, rohani dan kepemimpinan. Hal ini dapat dilihat dari uraian berikutnya:

Jumlah buku mengenai kepemimpinan tidak terbilang banyaknya. Minat terhadap kerohanian juga berkembang pesat dan ini tercermin dari bertambahnya buku-buku dengan topik terkait. Akan tetapi, gabungan dari kedua unsur itulah yang memberikan banyak solusi bagi sebuah masyarakan yang lapar akan sebuah visi dan kepemimpinan yang lebih berkembang. ${ }^{64}$

Namun demikian menurut Alan E. Nelson

Untuk memahami kepemimpinan rohani, kita tidak dapat sekedar mempelajari kepemimpinan dan kemudian mempelajari kerohanian dengan asumsi bahwa kedua unsur yang berbeda ini akan menyatu dengan sendirinya. Kepemimpinan rohani memiliki warna tersendiri. Karakteristik-karakteristik kepemimpinan rohani adakalanya sangat berbeda dari unsur kepemimpinan maupun unsur kerohanian yang berdiri sendiri-sendiri. ${ }^{65}$

Pada sisi yang lain Alan E. Nelson juga mengatakan,

Kepemimpinan rohani tidak hanya berarti bahwa orang yang bersangkutan lebih rohani dibandingkan dengan orang lain. Setiap manusia dapat menjadi orang rohani dan bertumbuh secara rohani. Allah memberi kita para pemimpin, khususnya sebagai sarana untuk mewujudkan pertumbuhan dan perubahan di gereja, bisnis, maupun organisasi sehingga orang-orang dapat lebih merasa puas dan terlayani. Kepemimpinan rohani bukan semata-mata berbicara mengenai para pemimpin yang percaya kepada Yesus secara pribadi atau yang mengklaim dirinya rohani, melainkan penyatuan dua unsur itu sehingga kerohanian dapat memaksimalkan kepemimpinan dengan cara-cara yang tak mungkin dicapai dengan cara lain. ${ }^{66}$

\section{Analisis Pandangan Para Tokoh Kepemimpinan Dalam Kerangka Integrasi}

Melihat hubungan kepemimpinan rohani dan sekuler dari pemikiran para tokoh kepemimpinan Kristen yang disampaikan secara impisit maupun eksplisit ada dua aspek yang memiliki kesamaan di antara mereka: Pertama, pandangan tentang perbedaan filosofis atau nilai yang melandasi kepemimpinan rohani dan sekuler, Kedua, pandangan tentang adanya kontribusi kepemimpinan sekuler terhadap kepemimpinan rohani.

Walaupun para tokoh memiliki kesamaan dalam dua aspek tersebut, namun dalam pendekatan terhadap hubungan antara kepemimpinan rohani dengan sekuler tidak sama. Henry dan Richard Blackaby serta Stacy T. Rinehart beranggapan bahwa kepemimpinan rohani dan sekuler tidak bisa disatukan. Henry dan Richard Blackaby serta Stacy T. Rinehart lebih melihat perbedaan filosofis sebagai hal yang tidak bisa menyatukan kepemimpinan rohani dan sekuler. Karena filosofisnya berbeda maka keduanya tidak bisa berelasi. Bahkan Henry dan Richard Blackaby menganggap kepemimpinan rohani lebih tinggi dari kepemimpinan dunia. Sedangkan John C. Maxwell, Yakob Tomatala mengakui keperbedaan nilai, namun kepemimpinan rohani dapat berelasi dengan kepemimpinan sekuler dengan proses transformasi. Sedangkan Robert K.Greenleaf, Ken Blanchard dan Phil Hodges adalah tokoh-tokoh yang mencoba pendekatan dengan menyatukan keduanya. Mengenai Alan E. Nelson, sebenarnya tokoh inilah yang secara eksplisit mengkonsepkan tentang integrasi, namun demikian pandangannya bukan integrasi kepemimpinan rohani dan sekuler, tetapi kerohanian dan kepemimpinan.

Perlu dipahami bahwa apa yang ditempuh Blackaby dan Stacy dalam pendekatan kedua bentuk kepemimpinan tersebut terutama termotifasi selain perbedaan nilai adalah juga untuk menghindarkan gereja dari praktek kepemimpinan sekuler murni, karena gereja dianggap mulai tidak mempedulikan nilai-nilai kepemimpinan rohani tetapi mendasarkan kepada kepemimpinan sekuler.

\footnotetext{
${ }^{64}$ Alan E. Nelson, Spirituality and Leadership (Bandung : Yayasan Kalam Hidup, 2002), 19.

${ }^{65}$ Ibid., 18.

${ }^{66}$ Ibid., 30.
} 
Bagi John C. Maxwell, kepemimpinan lebih kepada membangun sistim nilai, bagaimana nilai-nilai kepemimpinan Kristen itu mentransformasi hidupnya, selanjutnya akan berfungsi menjadi filter. Sistim nilai ini seperti seperti orang yang memakai baju, yang penting cocok dan serasi, sesuai ukurannya, sesuai selera model dan warnanya. Kalau tidak cocok dengan ukuran, selera bentuk dan warnanya ya tidak dipakai.

Hal yang sama juga dilakukan Yakob Tomatala, dengan mendasarkan kepemimpinan rohani berdasarkan transformasi nilai, "Alkitab adalah dasar bagi falsafah, nilai dan dinamika kepemimpinan Kristen. Dasar/falsafah ini harus menjadi landasan kepemimpinan Kristen yang mewarnai nilai, sifat dasar, falsafah kehidupan, pola dan perilaku kepemimpinan dalam konteks. ${ }^{\text {"67 }}$

Kepemimpinan Pelayan (Servant Leadership) sebenarnya dikembangkan dan di peraktekkan lebih jauh dalam dunia sekuler. Melalui kepemimpinan pelayan yang dikembangkan di dunia usaha bisa dilihat bahwa konsep dan praktek kepemimpinan memiliki nilai, tolak ukur, standar dan kriteria bagaimana seharusnya kepemimpinan itu harus dilakukan, berdampak dan sampai kepada tujuan.

Beberapa prinsip penting tentang kepemimpinan pelayan adalah: "Memastikan bahwa kebutuhan utama orang lain terlayani. Batu uji terbaik adalah: apakah mereka yang dilayani berkembang sebagai manusia yang utuh; apakah ketika dilayani mereka menjadi lebih sehat, arif, bebas, mandiri dan berkeinginan menjadi pelayan? apakah dampaknya bagi orang-orang yang paling lemah dalam masyarakat? Apakah mereka menerima kebaikan atau paling sedikit tidak terhambat dalam menggunakan kesempatan-kesempatannya?" ${ }^{6}$. Karena konsep ini dikembangkan dalam dunia usaha tentu ada motif-motif yang berbeda dengan kepemimpinan yang diterapkan dalam dunia rohani khususnya mengenai pertanggung jawaban tertinggi dan tujuan profit.

Metode yang yang sama juga dikembangkan oleh Ken Blanchard dan Phil Hodges, bahwa ada nilai-nilai yang dapat dipertemukan antara kepemimpinan rohani dan sekuler, kemudian membentuk sistem baru yang disebut kepemimpinan pelayan.

Tulisan Alan E. Nelson yang secara eksplisit menyadari perlunya apa yang disebut penyatuan kerohanian dengan kepemimpinan. Namun demikian, apa yang dilakukan Alan E. Nelson sebenarnya tidak mengintegrasikan kepemimpinan rohani dan sekuler tetapi kerohanian dengan kepemimpinan. Perpaduan tentang kerohanian dengan kepemimpinan sehingga melahirkan "Kepemimpinan Rohani."

Alan E. Nelson ingin mewujudkan seorang pemimpin Kristen yang rohani bukan pemimpin Kristen yang merupakan integrasi antara kepemimpinan Kristen dengan kepemimpinan sekuler. Memang "spiritualitas" di dalamnya mengandung nilai-nilai kepemimpinan Kristen, tetapi nilai-nilai rohani yang dimaksud Alan tidak berbicara secara langsung atau khusus tentang kepemimpinan rohani tetapi bersifat umum.

Hal yang bisa dipelajari dari Alan adalah, walaupun Alan E. Nelson tidak mengintegrasikan kepemimpinan rohani dan sekuler, namun ada beberapa pokok pikirannya tentang integrasi kerohanian dan kepemimpinan yang bisa dijadikan masukan mengapa perlu integrasi kepemimpinan rohani dan sekuler: Pertama, "Kita mendapati dasar agama terlalu lunak, dasar teknologi terlalu keras, dan kita tengah mencari sesuatu yang ada di antaranya, yang benar-benar tepat. Kita mulai menyadari bahwa kebenaran ada diluar batasan-batasan dari sesuatu yang dapat dijelaskan, dapat diamati, dan kadang-kadang, bahkan dapat dipikirkan." Kedua, "Ketika kerohanian diperlakukan

\footnotetext{
${ }^{67}$ Judul Bab III dalam buku Kepemimpinan Kristen; Yakob Tomatala, Kepemimpinan Kristen (Jakarta : YT Leadership Foundation, 2002), 89.

${ }^{68}$ Jeffrey Samosir, "Kepemimpinan yang Melayani," www.gkimy.or.id; diakses tanggal 29 Juni 2009; tersedia di http://www.gkimy.or.id/index.php?id=160

${ }^{69}$ Alan E. Nelson, Spirituality and Leadership (Bandung: Yayasan Kalam Hidup, 2002), 19.
} 
sebagai sesuatu yang penuh rahasia dan hanya diketahui oleh beberapa orang tertentu saja, kerohanian itu akan kehilangan pengaruhnya yang kuat." ${ }^{, 70}$ Ketiga, "Orang-orang bertipe profetik mungkin tampak seperti pemimpin saat menyodorkan visi-visi yang radikal. Sering mereka mengorbankan reputasi maupun hidup mereka sendiri. Tetapi, pemimpin yang sejati cakap mengatur anak buahnya untuk mencapai sasaran. Menyampaikan seruan untuk suatu perubahan biasanya lebih mudah dilakukan daripada mewujudkan perubahan dengan gigih namun tidak kentara, seperti yang dituntut oleh para pemimpin yang berjuang untuk melakukan perubahan." ${ }^{71}$ Keempat, "Di dunia sekuler, kepemimpinan yang lebih baik berarti tidak sekadar menggunakan hikmat manusia, tetapi juga jiwa, intuisi, maupun kepekaan. Bagi para pemimpin Kristen, ini berarti mengalihkan perhatian dari diri sendiri kepada Allah." ${ }^{72}$ Kelima, "Banyak pemimpin sangat tidak cakap karena mereka hanya berorientasi kepada tugas. Bagi mereka, kekuatan tambahan dari buah Roh mengimbangi titik-titik yang sangat lemah. Akibatnya, para pengikut mereka merasa disukai dan dihargai. Para pemimpin rohani, menggunakan kelebihan ini sebagai cara untuk memotivasi, merekrut, dan menerima komitmen dari anggota-anggota tim." ${ }^{, 73}$ Keenam, "Di abad dua puluh satu, para pengikut mencari pemimpin yang tidak mengkotak-kotakkan hidupnya, melainkan yang utuh dan autentik. Pemimpin yang rohani tidak dapat memisahkan jiwa mereka dari peran mereka sebagai pemimpin. Di tempat kerja maupun dalam pertemuan-pertemuan bisnis, mereka merasa senyaman dan seleluasa seperti dalam ibadah dan kehidupan rohani mereka. Orang yang memisahkan perannya sebagai pemimpin dari kehidupan rohaninya akan tampak menafik dan tidak bisa dipercaya." ${ }^{74}$ Ketujuh, " Para pemimpin tidak boleh hanya memimpin dengan otak, tetapi juga dengan hikmat, petunjuk, dan kuasa yang berasal dari jiwa. Orang-orang merindukan pemimpin yang bersedia memimpin dengan pikiran serta hati dan yang mampu mengenali sisi rohani anak buahnya." ${ }^{75}$

Apa yang disampaikan oleh Alan merupakan bagian dari proses integrasi kepemimpinan rohani dan sekuler, bahwa dalam proses integrasi menghasilkan "kepemimpinan rohani" yang berbeda dari sebelumnya, tetap saja tidak terlepas dari nilai-nilai teologis Kristen seutuhnya.

Berkenaan dengan pemikiran para tokoh tentang korelasi antara kepemimpinan rohani dengan sekuler dalam konteks integrasi dapat diperoleh garis besar pemikiran, antara lain : Pertama, kepemimpinan rohani dan sekuler bisa berintegrasi. Sebab masingmasing kepemimpinan, baik rohani maupun sekuler memiliki nilai kepemimpinan yang bisa diterima untuk saling memberikan kontribusi; Kedua, Kepemimpinan pelayan sebagai model kepemimpinan rohani. Kepemimpinan pelayan adalah bentuk kepemimpinan yang lebih teraktualisasi sebagai model kepemimpinan rohani sebagai proses integrasi kepemimpinan rohani dan sekuler.

Pertama, kepemimpinan rohani dan sekuler bisa berintegrasi. Adanya kesamaan dalam pandangan bahwa kepemimpinan sekuler bisa memberikan kontribusi bagi kepemimpinan rohani, sebenarnya merupakan bukti bahwa di dalam kepemimpinan sekuler juga ada nilai-nilai kebenaran yang bisa bertemu dengan nilai-nilai kebenaran dalam kepemimpinan rohani.

Argumen bahwa perbedaan filosofis antara kepemimpinan rohani dengan sekuler sebagai sebab tidak bisa merelasikan keduanya sebenarnya melahirkan dua asumsi: Pertama, menganggab bahwa di dalam kepemimpinan sekuler tidak ada nilai-nilai yang dianggap benar, ini bertentangan dengan pengakuan adanya kontribusi kepemimpinan sekuler terhadap kepemimpinan rohani. Berdasarkan prinsip integrasi "All Truth is God's

\footnotetext{
${ }^{70}$ Alan E. Nelson, Spirituality and Leadership (Bandung: Yayasan Kalam Hidup, 2002), 22

${ }^{71}$ Ibid.22.

${ }^{72}$ Ibid., 25

${ }^{73}$ Ibid. 25

${ }^{74}$ Ibid., 26

${ }^{75}$ Ibid., 21
} 
Truth" maka hal mendasar yang perlu dilakukan adalah menemukan kebenaran pada masing-masing dari kepemimpinan rohani dan sekuler kemudian mempertemukannya menjadi satu kesatuan.; Kedua, berkenaan dengan nilai yang melahirkan aplikasi bahwa nilai atau filosofis akan mempengaruhi praktek, adalah benar. Permasalahannya adalah apakah semua dasar filosofis kepemimpinan sekuler semuanya tidak baik. Selain itu perlu juga dipahami apa yang dijelaskan David H. Maisher bahwa pada sisi yang lain di dalam kepemimpinan ada juga perbedaan antara nilai yang dianut dan nilai dalam praktek atau pelaksanaan," Ada perbedaan antara "nilai-nilai yang mereka anut" (yang mereka bilang mereka percayai) dan "nilai-nilai dalam tindakan nyata" (bagaimana mereka secara aktual menghayati kehidupan profesional mereka)". ${ }^{76}$

Nilai-nilai yang di percayai sebagai dasar kepemimpinan bersifat moril dan motif sedangkan nilai-nilai dalam tindakan nyata merupakan cara, tolak ukur, standar pengelolaan atau kinerja untuk mencapai tujuan. Dengan demikian nilai-nilai filosofis kepemimpin tidak selalu berkaitan dengan aplikasi karena sifat dari nilai masing-masing berbeda.

Hal mendasar yang harus dipahami dalam proses integrasi kepemimpinan rohani dan sekuler, ialah integrasi itu bersifat menyeluruh terhadap keseluruhan kepemimpinan. Kepemimpinan dipandang secara utuh bukan bagian demi bagian, dan di dalam keseluruhan itulah dicoba ditemukan hal-hal yang sama (tabel 3) dan kontribusikontribusi yang diberikan keduanya (tabel 4). Inilah yang dilakukan dalam integrasi kepemimpinan rohani dan sekuler. Dan proses integrasi itu sendiri tidak bersifat mekanis tetapi secara internal pada setiap individu.

Tabel 3 : Beberapa Persamaan Kepemimpinan Sekuler dan Rohani

\begin{tabular}{|l|c|}
\hline \multicolumn{1}{|c|}{ Kepemimpinan Sekuler } & Kepemimpinan Rohani \\
\hline -Berorientasi kepada manusia & -Berorientasi kepada manusia (selain \\
-Mengupayakan kesejahteraan manusia & kepada Allah sebagai tujuan tertinggi) \\
-Untuk mencapai tujuan dan visi & -Mengupayakan kesejahteraan manusia \\
melalui berbagai proses : & (selain kekekalan ) \\
-Mempengaruhi, menolong orang/ & -Untuk mencapai tujuan dan visi melalui \\
kelompok. & berbagai proses : \\
-Memberdayakan dan memobilisasi & -Mempengaruhi, menolong orang/jemaat \\
orang. & -Memberdayakan, mengembangkan, dan \\
-Berupaya bekerja dengan nilai, prosedur, & memobilisasi orang dan jemaat \\
sistem dan pola, dll & -Berupaya bekerja dengan nilai, prosedur, \\
& sistem dan pola, dll \\
\hline
\end{tabular}

Tabel 4 : Beberapa Kontribusi Kepemimpinan Sekuler dan Rohani dalam Proses Integrasi

\begin{tabular}{|l|l|}
\hline \multicolumn{1}{|c|}{ Kepemimpinan Sekuler } & \multicolumn{1}{c|}{ Kepemimpinan Rohani } \\
\hline -Melakukan pendekatan ilmiah tentang & -Bersifat substansi : \\
prilaku manusia dan kepemimpinan & -Menjelaskan siapa sebenarnya \\
-Di dalam kepemimpinan selalu ada & manusia ? \\
aplikasi praktis bagaimana: & -Kepada siapa manusia bertanggung \\
-Memotivasi, mengambil keputusan dan & jawab ? \\
memberikan arah & -Bagaimana hubungan manusia dengan \\
-Cara mencapai tujuan dan visi & Manusia? \\
-Cara berelasi dengan orang lain & -Mengapa manusia bekerja, berteman, \\
-Cara meningkatkan sumber & bermitra. \\
daya manusia untuk lebih efektif, & - Tuntunan moral, motif, dan integritas \\
produktif dan tepat sasaran & yang melandasi kepemimpinan \\
dll. & -Apa tujuan tertinggi kepemimpinan \\
& -dll \\
& \\
\hline
\end{tabular}

${ }^{76}$ David H. Maister, Profesionalisme Sejati ( Jakarta : PT Gramedia, 1998), 10 
Kedua, kepemimpinan pelayan sebagai model kepemimpinan rohani. Model kepemimpinan Kristen sebagai hasil integrasi kepemimpinan rohani dan sekuler lebih teraktualisasi dalam model kepemimpinan hamba yang ditemukan Robert K.Greenleaf. Tentu bentuk kepemimpinan hamba yang dilakukan dalam dunia rohani bukan bisnis. Salah satu aspek terpenting dari kepemimpinan ini adalah apa yang disebut oleh Ken Blanchard dan Phil Hodges "memimpin sekaligus melayani", hal ini meliputi melakukan fungsi-fungsi kepemimpinan:" Menetapkan tujuan dan visi, mengkomunikasikan gambaran yang meyakinkan tentang masa depan, menjelaskan dan memberi contoh tentang nilai, struktur, dan perilaku yang Anda kehendaki agar orang-orang Anda jalankan, menciptakan lingkungan pemberdayaan, mendorong ke dasar piramida untuk mendukung orang-orang yang bertanggung jawab dalam pelayanan langsung, menunjukkan hormat kepada orang lain dan menempatkan pertumbuhan dan perkembangan orang sebagai hal yang sama pentingnya dengan menyelesaikan visi. ${ }^{77}$

Penjelasan lebih lanjut dikemukakan Ken Blanchard dan Denis Carey, "Kepemimpinan adalah tentang pergi ke suatu tempat. Kepemimpinan yang hebat yang memimpin sekaligus melayani petama-tama berfokus untuk mengembangkan visi yang menggugah dan pengetahuan yang jelas tentang arah yang dituju perusahaan." "Sebuah visi menggugah yang memberitahukan orang-orang dalam organisasi Anda, siapa Anda (tujuan Anda), ke mana Anda akan pergi (gambaran Anda tentang masa depan), dan apa yang akan menuntun perjalanan Anda (nilai-nilai Anda)."79 "Visi dan arah yang jelas dimulai dari manajemen puncak dan harus dikomunikasikan ke seluruh organisasi oleh kepemimpinan. Meskipun manajemen puncak harus melibatkan orang-orang dalam membentuk arah, tanggung jawab akhir untuk memiliki visi dan mengkomunikasikan ke seluruh organisasi tetap berada di tingkat tinggi dan tidak dapat didelegasikan"80.

Selanjutnya menurut Ken Blanchard dan Denis Carey, "Begitu visi ditetapkan, sasaran dan strategi yang sudah ditetapkan dapat ditempatkan dalam konteks peringkat yang lebih tinggi, dan peran kedua dari kepemimpinan pelayan-implementasi-dimulai. Saat inilah bagian 'melayani' dari kepemimpinan pelayan mulai berfungsi." ${ }^{\text {1 }}$ Dan "menyenangkan setiap orang bukan tujuannya ; melayani visi dan arahlah tujuannya." 82

\section{KESIMPULAN}

Pertama, permasalahan kepemimpinan gembala pada dasarnya merupakan persoalan mengenai substansi kepemimpinan gembala itu sendiri. Persoalan ini bukanlah sebatas masalah praktis melakukan kepemimpinan atau tidak, tetapi bagaimana gembala sebagai individu yang seutuhnya dalam kepemimpinan. Pribadi yang di dalamnya secara being, thinking dan doing adalah pemimpin.

Kedua, untuk "menjadi" yang secara substansi seutuhnya dalam kepemimpinan gembala, maka perlu dilakukan pendekatan integrasi kepemimpinan Kristen dan sekuler. Pendekatan ini dalam bentuk menemukan kebutuhan dan kebenaran masing-masing bidang sehingga melahirkan "the integrated life" dalam pribadi kepemimpinan gembala.

\footnotetext{
${ }^{77}$ Ken Blanchard dan Phil Hodges, Lead Like Jesus ( Tangerang : Agromedia Pustaka, 2007), 149-150

${ }^{78}$ Frances Hesselbein and Marshal Goldsmith, The Leader of The Future; Ken Blanchard dan Dennis, Meraih Kembali Kepercayaan Publik, (Jakarta : Penerbit PT Elex Media Komputindo, 2008), 183

${ }^{79}$ Ibid. 183

${ }^{80}$ Ibid., 183-184

${ }^{81}$ Ibid., 184

${ }^{82}$ Frances Hesselbein and Marshal Goldsmith, The Leader of The Future; Ken Blanchard dan Dennis, Meraih Kembali Kepercayaan Publik, ( Jakarta : Penerbit PT Elex Media Komputindo, 2008), 185
} 
Ketiga, melalui keutuhan pribadi kepemimpinan gembala maka gembala akan menjalankan aspek-aspek kepemimpinan dalam proses penggembalaan. Bahwa gereja perlu "dikelola" dengan baik dan benar sesuai prinsip-prinsip kepemimpinan.

Keempat, Proses integrasi kepemimpinan rohani dan sekuler dalam proses penggembalaan adalah suatu dinamika yang tidak bersifat mekanis dan hanya berhenti pada satu titik. Proses ini merupakan suatu interaksi yang tidak pernah berhenti pada diri gembala. Interaksi ini melibatkan internalisasi yang menyeluruh terhadap filosofis dan nilai-nilai teologis Kristen sehingga mengalami transformasi pada individu. Pada saat yang sama perlu juga memahami secara substansi mengenai kepemimpinan sekuler sehingga melahirkan suatu interaksi yang menyeluruh sebagai proses integrasi antara keduanya. Dan proses integrasi secara ideal dapat terjadi bila invidu secara fundamental memahami teologi Kristen yang di dalamnya meliputi prinsip-prinsip kepemimpinan rohani dan dilain pihak memahami juga prinsip-prinsip kepemimpinan sekuler. Selanjutnya relasi dalam proses integrasi akan terjadi di dalam diri dan membentuk "integral life" keutuhan pribadi kepemimpinan.

\section{Saran-Saran}

Pertama, bagi gereja, institusi pendidikan teologi dan pemimpin Kristen. Perlu adanya pendalaman dan eksploitasi secara utuh, menyeluruh yang bersifat intensif dan konsisten terhadap Alkitab untuk menemukan prinsip-prinsip kepemimpinan Kristen. Pendalaman ini tidak hanya melahirkan konsep-konsep kepemimpinan dalam tataran teologis, tetapi juga bersifat aplikasi. Penulis beranggapan bahwa bila kepemimpinan Kristen terus digali, dikaji, dikembangkan dan coba diaplikasikan dengan kebutuhan secara prakstis, maka kepemimpinan Kristen akan semakin memperoleh bentuknya. Pada proses ini integrasi diperlukan untuk menolong kepemimpinan Kristen bisa terus digali, terukur, sistimatis dan tepat guna.

Kedua, kepada pribadi gembala atau pemimpin Kristen yang melakukan proses integrasi kepemimpinan rohani dan sekuler. Meskipun proses integrasi kepemimpinan rohani dan sekuler melahirkan kepemimpinan gembala yang mampu melakukan tugastugas kepemimpinan secara terukur, sistimatis dan tepat guna, bukan berarti bahwa kepemimpinan gembala menjadi kepemimpinan yang bersifat kaku dan hanya berdasarkan analisis manusia semata. Prinsip-prinsip kepemimpinan gembala tidak bisa terlepas dari melihatkan Allah sepenuhnya. Bahwa kepemimpinan Kristen adalah panggilan Allah. Sebab itu doa dan penyerahan diri kepada Allah untuk mencari kehendak-Nya adalah faktor substansi yang tidak terpisahkan dan diabaikan dalam proses penggembalaan. Proses integrasi juga tidak hanya sebatas menemukan prinsipprinsip kepemimpinan Kristen kemudian menyatukannya dengan prinsi-prinsip kepemimpinan sekuler, tetapi lebih dari itu transformasi nilai-nilai Kristen harus terjadi terlebih dahulu dalam diri orang tersebut, selanjutnya harus menghidupinya dalam realita sehari-hari. Dalam konteks seperti inilah integrasi dapat terwujud. Sebab kalau faktor ini dikesampingkan, maka kepemimpinan gembala tidak lebih dari cara manusia semata. 


\section{Kamus}

\section{KEPUSTAKAAN}

Tim Penyusun Kamus Pusat Pembinaan dan Pengembangan Bahasa. Kamus Besar Bahasa Indonesia, Jakarta: Balai Pustaka, 2001.

Ensiklopedi Alkitab Masa Kini Jilid A-L, RAS/MHS, Gembala. Jakarta: Yayasan Komunikasi Bina kasih/OMF, 1992.

\section{Buku-Buku}

Bakker, Anton. dan Drs.Achmad Charris Zubair, Metodologi Penelitian Filsafat. Yogyakarta: Penerbit Kanisius, 1994.

Blackaby, Henry dan Richard Blackaby, Kepemimpinan Rohani. Jakarta: Gospel, 2009.

Hesselbein, Frances. and Marshal Goldsmith, The Leader of The Future; Usman A. Gani, Pemimpin Integrator. Jakarta : Penerbit PT Elex Media Komputindo, 2008.

Holmes, Arthur F. Segala Kebenaran adalah Kebenaran Allah. Surabaya: Penerbit Momentum, 2000.

Maxwell, John C. Jadilah Orangyang Berorientasi Manusia. Batam Centre: Interaksa, 1999.

Myron, Rush. Manajemen Menurut Pandangan Alkitab. Malang: Gandum Mas, 2002.

Nelson, Alan E. Spirituality and Leadership. Bandung: Yayasan Kalam Hidup, 2002.

Poli, W.I.M. “Manajemen Perilaku Organisasi” (Makassar: STT Jaffray, 2008).

Sumaryono, E. Hermeneutik, Sebuah Metode Filsafat (Yogyakarta: Penerbit Kanisius, 1999), 23.

Susabda, Yakub. "Integrasi Teologi dan Psikologi”, (Jakarta : STTRII, 2000).

Tidball, Derek J. Teologi Penggembalaan. Malang: Gandum Mas, 1998.

Tomatala, Yakob. Kepemimpinan Yang Dinamis. Jakarta: YT Leadership Foundation; Malang: Penerbit Gandum Mas, 1997.

Yukl, Gary. Kepemimpinan Dalam Organisasi. Jakarta: PT Indeks : 2005.

\section{Internet}

Hariyanto, Muhsin. "Hermeneutik : Sebuah Pengantar" Fai.elcom.umy.ac.id; diakses tanggal 1 April 2009; tersedia di http://fai.elcom.umy.ac.id/mod/forum/discuss.php?d=89

Samosir, Jeffrey. "Kepemimpinan yang Melayani," www.gkimy.or. id; diakses tanggal 29 Juni 2009; tersedia di http://www.gkimy.or.id/index.php?id=160 